\title{
The Effect of E-Banking on Employees' Job Security (Case study: selected branches of Kermanshah commerce banks)
}

\author{
Shahryar Shirzadi ${ }^{1}$, Maryam Nazari Montazer ${ }^{2}$, Mohammad Ahmadpour ${ }^{3}$ \\ ${ }^{1}$ Department of Management, Sanandaj Branch, Islamic Azad University, Sanandaj, Iran \\ ${ }^{2}$ Department of Business Management, Kerman Science and Research Branch, Islamic Azad University, \\ Kerman, Iran. \\ ${ }^{3}$ Department of Management, Kermanshah Branch, Islamic Azad University, Kermanshah, Iran
}

\begin{abstract}
In the organizational life job security is one of the issues that engaged employees in organizations and consumed a part of mental and psychological energy of organization. Whenever workers reach a satisfactory level of relinquish, they should use the mental and physical energy for organization and decrease the human tension in the organization. as well, developing e-banking as one of the applications of information technology and communication effected monetary and banking markets in developed countries, and forced banking industry to apply such innovations. Accordingly, in this article which is applied one based on its purpose and is descriptive- correlative based on data, tried to analyze the effect of applying developed banking technology on job security of banks. To this end, 385 questionnaires were distributed among employees and managers of selected commerce banks of Kermanshah and after collecting data with appropriate statistical tests, they were analyzed. Result of the study indicated that using services of e-banking, electronic transferring of money, and using telephone bank had negative and significant impact on job security of employees.
\end{abstract}

Key terms: Job Security, electronic banking, telephone bank, electronic transferring of money, e-banking services.

\section{Introduction}

In the previous decade, information technology had tremendous effects on banking industry. This issue caused banks to be able to offer products and specific services for the customers. It is about 200 years that banks via their branches offer services to customers, but by advent of new technology, offering financial services to customers has been changed. For example ATMs replaced with counters and credit cards and electronic cash replaced banking transactions. Banks obtain different benefits of offering e-banking services that of them we can refer to the lower price of transactions, offering 24 hours services, increasing efficiency in the process of banking and... (Taghavifard et al, 2010). The term electronic banking as distance banking services are offered by legal banks or their agents via electronic machines. In other words, the term e-banking is a process in which customer may do the e-banking transactions without referring to counters of banks. E-banking has systems enabling customers to do their transactions without referring to the bank and makes it possible to have access to their accounts and to benefit from the entire financial services (SAMA, 2010).

E-banking is increasingly accepted in most of the world countries, so that the rate of e-banking communications exceeded over 50\% (Tropikarnin et al, 2004). In the banking system doing affaires rapidly and lack of wasting the time are the most important elements of achievement in banking competition, and customers as the main agents of specifying this competition takes technology and seed valuable in grading the technical expert of banks. In the new banking, expanding new banking especially e-banking services are necessary and therefore for being more efficient banks require getting sufficient information from customers to perceive their needs and wishes to develop their relationships.

E-banking and taking new technologies have affected the job security of many workers. In their business, banks rely on internet, telephone, ATMs, the system of money transfer, electronic payment system and other electronic banking services that cause them to remain in the realm of economic competition. Therefore, ebanking causes decreasing reliance to banks in traditional methods and lack of employees' job security (Jannatul, 2010). E-banking can offer more rapid and trustable services and cause more satisfaction of customers than traditional and manual methods (Alabar, 2012). The recent banking requires innovative methods, customer based, effective technologies, servicing, and ideal services for customers that states a bank is more successful that is able to attract more resources and then durance, permanent survival, and higher efficiency. Meantime, ebanking is the best and most effective item for banks to achieve these goals. Therefore, in this study it was tried to analyze the effect of using new banking technologies and their effects on security of the bank employees.

The concept of e-banking and its impact on job security and bank efficiency

E-banking entails the entire electronic channels which customers are using to access their accounts and transferring money between accounts or paying their bills. These channels included internet, mobile, telephone, 
digital television and MTAs (Dandaani, 2008). E-banking using web and internet technology enables customers to do their financial activities in a virtual environment. Difference between e-banking and traditional banking is that for access to banking services via internet there is no need for installing specific software, but banking services can be accessible via general network of internet and through internet the customer can be connected to his/her account (Alsajjan and Dennis, 2010). By developing web application, e-banking have developed. And by increasing the level of access to the internet offering such services can be developed. E-banking resulted in developing geographical access to the banks that increased simplicity of working for the customer and decreases the cost of transactions. Also, this method lets customers to have access to their financial information directly to do their banking operations without paying attention to lace and referring to the bank via their personal computer in a far distance place. This method of banking is a new method for banks to have interaction with their customers (Chi et al, 2007).

E-banking services, have improved the efficiency effectiveness of services and by rapid offering of them to customers. Therefore, e-banking have been changed to a necessary element in banking industry and a part of modern life of people. Accordingly, banking authorities should not ensure that approving e-banking result in direct loss of employees' job and beforehand retiring of them. In this respect different studies were done that some of them will be referred to here. Atiku et al (2011) studied the effects of e-banking on employees' job security of Nigeria banks. Result showed that using e-banking is not make losing job and beforehand retirement of employees. In addition, using ATMs and other payment systems were influential on job stability of workers.

Olanipekun et al (2013) studied the effect of e-banking on performance of human resources and customer satisfaction. Purpose of this study was determining the method of using electronic banking to increase the efficiency of banking services. Result of this study indicated that e-banking has a positive and significant impact in offering banking services and caused increasing customer satisfaction. Also, using e-banking services caused improving employees' performance and human resources of banks. Adewoye (2013) studied the using of e-banking services as a main factor among commercial banks. This study aim was to analyze the effect of ebanking using cell phone in commercial banks of Lagos. Therefore, 140 questionnaires were distributed among employees. Result of this study indicated that phone banking caused customer satisfaction, saving the time, rapid and trustable transactions and saving the price of banking services.

The concept of job security and its components

In the concept of job security subjects such as job changes, losing the job, lack of access to roper job are included. Therefore, in industrial and organizational psychology job security is major creator of job satisfaction (Shakerinia et al, 1997). Supplying needs are totally clear and common among people. We tend to be secure from life damages such as accident, diseases, and economic and job instability. Accordingly, people and organizations interested to ensure they are immune from such catastrophes (Soltani, 2009).

Components of job security are:

-Emphasizing on job by individuals represents job stability that such focusing prevents individuals from having two jobs and forms a part of job security.

-Fewer placements in job represents job security that is due to expert and influence and when individuals could be expert in one occupation a part of their job security can be formed.

-Selecting proper job provides the ground for improving interests in working that is directly related to job security.

-Job satisfaction result in innovation during working and finally innovations strengthen job security of workers.

-Economic satisfaction causes assurance of the person in the works and the same senses forms among workers that itself plays a significant role in job security. Of the elements of job security is emotionality of the working environment that helps building healthy human being and when human being improved his/her personality by working, their job security will be supplied.

-The sense of security in working results in releasing from job pressure and consequently a part of employees job security will be supplied via job pressures.

-Dependency of individual to organization indicates job security that result in organizational commitment.

-When workers of one organization defend their organization, they validate their organization directly and indirectly which result in supplying job security of workers.

\section{Research Methodology}

Population of this study includes workers of commercial banks of Kermanshah which were asked about internet banking services. To specify samples the table of Kerjsari and Morgan was used. According to the volume of population samples were considered 385 individuals, which for certainty 500 questionnaires were distributed to participants in different branches. Necessary data in the present study which was applied based on 
purpose and descriptive- correlative according to data, was gathered using library method including books, articles, journals, research reports, documents, present documents and using internet, also questionnaire and interviewing managers and experts in related issues were collected. Necessary data in the present study using one close questionnaire using five item responses of Likert was done. Questionnaires were distributed by attending in selected branches. Therefore in present study, after preparing the research design and preparing theoretical principles a questionnaire was prepared for the samples of the study and after collecting data conclusion and suggestions were derived.

Determining stability of the questionnaire:

\section{Data Analysis}

Stability is a technical feature of measurement. This concept indicates that to what extent in the same conditions the same result will be concluded.

In this study to specify stability Cronbach's Alpha method was used. As data of the following table indicated the questionnaire is reliable and stable.

Table 1 Cronbach's Alpha of the questionnaire

\begin{tabular}{|c|c|}
\hline Questions & Sample Cronbach's Alpha \\
\hline 30 & 0.77 \\
\hline
\end{tabular}

Investigating demographic variables for better understanding the nature of population and more familiarity with research variables before data analysis is totally necessary to describe these data. As well statistical description of data is a step to distinguish dominant patterns on them and a basis for specifying relationship between variables that are used in this study. Accordingly, in this study at first demographic variables of commercial banks of Kermanshah should be analyzed.

Table 2 frequency distribution of the variable of individuals' age in samples

\begin{tabular}{|r|r|r|r|}
\hline & & Frequency & Percentage \\
\hline Variable & 20 to 30 years & 43 & 11.11 \\
\hline & 31 to 40 years & 105 & 28 \\
\hline & 41 to 50 years & 145 & 37.66 \\
\hline & More than 50 & 92 & 23.89 \\
\hline & Total & 385 & 100 \\
\hline
\end{tabular}

According to the stated table 43 individuals of commercial banks $(11.11 \%)$ of present individuals in the sample are in the range of 20 to 30 years, and 105 individuals $(28 \%)$ were from 31 to 40 years, and 145 individuals (37.66\%) were from 41 to 50 years, and finally 92 individuals $(23.8 \%)$ were more than 50 years.

Table 3 Frequency distribution of gender

\begin{tabular}{|r|r|r|r|}
\hline & & Frequency & \multicolumn{1}{|c|}{ Percentag } \\
\hline Variable & Male & 274 & 71.1 \\
\hline & Female & 111 & 28.83 \\
\hline & Total & 385 & 100 \\
\hline
\end{tabular}

According to above table the number of women in the sample were 274 individuals $(71.1 \%)$, the number of men was 111 individuals $(28.83 \%)$ and the total number of individuals in the sample was 385 individuals.

Table 4 frequency distribution of level of education

\begin{tabular}{|l|c|c|c|}
\hline & & Frequency & Valid percentage \\
\hline Variable & Diploma & 30 & 7.79 \\
\hline & Associate diploma & 110 & 28.57 \\
\hline & License & 160 & 41.55 \\
\hline & Master of arts & 75 & 19.48 \\
\hline & Doctoral & 10 & 2.59 \\
\hline & Total & 385 & 100 \\
\hline
\end{tabular}

According to the above table, 30 individuals (7.79\%) were diploma, 110individuals (28.75\%) were associate diploma and 160 individuals (41.55\%) were license, 75 individuals(19.48\%) were Master of arts, and finally 10 individuals were specified with doctoral studies. 
Testing normality of variables (Kolmogorov-Smirnov)

To see if two or several samples are equally distributed or not, their experimental distribution should be studied to specify the rate of their similarity.

Kolmogorov-Smirnov is a statistical method which the maximum of horizontal distance between distributionsis used as a measure for the quality of their similarity. As many parametric tests are on the basis of normality of the data, it should be investigated to see if distribution of data in a society is selected in a sampling level of society with normal distribution. Therefore, before dealing with statistical analysis and investigating variables their distribution should be specified. Accordingly, using Kolmogorov-Smirnov test normality of data was investigated.

Decision making principle: $\mathrm{H} 0$ can be rejected at $95 \%$, if the sig level of Kolmogorov-Smirnov text was less than 0.05 ; hypotheses of this test are as follow:

H0: Data are normal.

H1: data are not normal.

Table 5 Kolmogorov-Smirnov test

\begin{tabular}{|c|c|c|c|}
\hline & Employees' job security & Electronic-money transfer & E-banking services telephone bank \\
\hline Smirnov test & $0 / 613$ & $0 / 262$ & $0 / 0751 / 98$ \\
\hline Sig level & $0 / 058$ & $0 / 083$ & $0 / 0077 / 055$ \\
\hline
\end{tabular}

According to the sig level of Kolmogorov-Smirnov test and the sig level values for variables of employees' job security, electronic money transfer, e-banking services and telephone bank were $0.058,0.083$, 0.077 and 0.055 respectively that were more than $0.05 \%$, therefore, we conclude that distributing the entire variables has been normal and we can use parametric methods for measuring research hypotheses.

\section{Testing Hypotheses}

First Hypothesis: using electronic money transfer has a positive and significant effect on employees' security? H0: using electronic money transfer don't have any positive and significant effect on employees' security H1: using electronic money transfer has a positive and significant effect on employees' security.

Table 6 Regression coefficients for the First Hypothesis

\begin{tabular}{|c|c|c|c|c|c|}
\hline Dependent variable & $\begin{array}{c}\text { Independent } \\
\text { variable }\end{array}$ & $\mathrm{B}$ & Standard error & $\mathrm{t}$ & (Prob)Sig level \\
\hline Employees' job security & $\begin{array}{l}\text { Money electronic } \\
\text { transfer services }\end{array}$ & -1.37 & 0.077 & 3.09 & 0.012 \\
\cline { 2 - 5 } & Stable value & 2.48 & 0.011 & 4.08 & 0.008 \\
\hline Specification coefficient & & 0.72 \\
\hline Fisher value & \multicolumn{3}{|c|}{0.0024} \\
\hline Fisher's sig level & \multicolumn{3}{|c|}{1.89} \\
\hline
\end{tabular}

In this hypothesis the value of determining coefficient was 0.72 that shows independent variable is able to predict the dependent variable. Watson Camera statistics was used to analyze independence of errors. When the value of Watson Camera statistics is in the distance from 1.5 to 2.5 the assumption of correlation between errors is rejected and we can use regression that in this hypothesis it is 1.89 that can be categorized in this range; therefore, the hypothesis of error independence is accepted. On the one hand, the sig level of Fisher test is less than 5\% showing that the model of this hypothesis is significant. In the above table the sig level of t-test is less than 5\%; therefore, the independent variable can affectdependent variable, as well, since regression coefficient of electronic money transfer is negative, by the way, the effect of this variable on employee's job security is reversal. Therefore, H0 indicating lack of effecting electronic money transfer on employees' job security is accepted. Second Hypothesis: using e-banking services has a positive and significant effect on employees' job security.

H0: using e-banking services don't have any positive and significant effect on employees' job security.

H1: using e-banking services has a positive and significant effect on employees' job security.

Table 7: regression coefficient for the second hypothesis

\begin{tabular}{|l|l|c|c|c|c|}
\hline Dependent variable & Independent variable & B & Standard error & t & (Prob)Sig level \\
\hline & E-banking services & -3.12 & 1.008 & 3.61 & 0.0029 \\
\cline { 2 - 6 } & Stable value & 1.098 & 0.23 & 2.57 & 0.0099 \\
\hline \multicolumn{3}{|l|}{ Specification coefficient } & \multicolumn{3}{c|}{0.63} \\
\hline
\end{tabular}


The Effect of E-Banking on Employees' Job Security (Case study: selected branches of Kermanshah

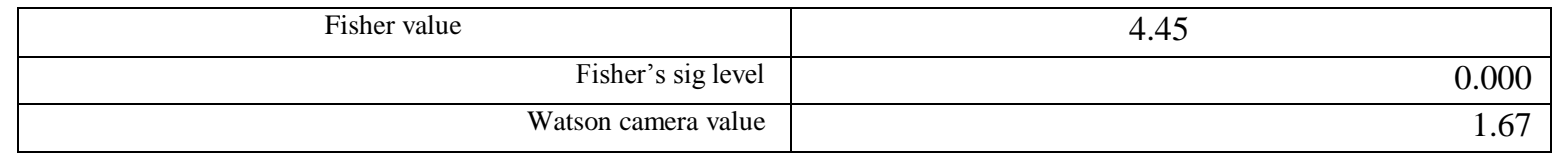

In this hypothesis the rate of determination coefficient was 0.63 that indicates independent variable can predict dependent variable. Watson Camera statistics was used for analysis of independence of errors. When the value of Watson camera statistics is in the distance of 1.5 to 2.5, the correlation coefficient between errors can be rejected and it is possible to use regression that in this hypothesis it is 1.67 allocated in this range; therefore, independence of errors can be accepted. On the one hand, the sig level of Fisher test is less than 5\%, it means that the model of this hypothesis is significant. In the stated table the sig level of t-test is less than 5\%; therefore, the independent variable has a negative effect on dependent variable; therefore, using electronic services has a negative and significant effect on employees' job security.

Third Hypothesis: using telephone bank has a positive and significant effect on employees' job security.

H0: using telephone bank don't have any positive and significant effect on employees' job security.

H1: using telephone bank has a positive and significant effect on employees' job security.

Table 8 regression Coefficient for the third hypothesis

\begin{tabular}{|c|c|c|c|c|c|}
\hline Dependent variable & Independent variable & B & Standard error & t & (Prob)Sig level \\
\hline \multirow{2}{*}{ Job security } & Telephone bank & -4.892 & 0.009 & 4.99 & 0.000 \\
\cline { 2 - 6 } & Stable value & 2.09 & 0.28 & 4.055 & 0.001 \\
\hline \multicolumn{2}{|c|}{ Specification coefficient } & & 0.71 \\
\hline Fisher value & & 5.98 \\
\hline & Fisher's sig level & & 0.001 \\
\hline
\end{tabular}

In this hypothesis the rate of determination coefficient is 0.71 indicating that independent variable is able to predict dependent variable. Watson Camera statistics is used to analyze error independence. When the value of Watson Camera statistics is from 1.5 to 2.5, the correlation hypothesis between errors can be rejected and regression coefficient can be used which in this hypothesis it is 2.14 allocating in this range. Therefore, the hypothesis of error independence is accepted. On the one hand the sig level of Fisher test is less than 5\%, stating that the model is significant. In the stated table the sig level of t-test is less than 5\%; therefore, the independent variable can has reverse effect on dependent variable. Therefore, using telephone bank has a negative and significant effect on employees' job security.

\section{Discussion And Conclusion}

E-banking services resulted in developing banking services and increasing customers' satisfaction that consequently resulted in increasing efficiency and profitability of banks. E-banking have broken the borders of traditional banking and caused connecting banks to the foreign countries. Accordingly, using these services caused workers not to benefit from security and job stability, because consequent use of these services result in lack of attending customers to banks and result in beforehand retiring of workers. Result of this study showed that in the view of commercial bank employees of Kermanshah, using electronic money transferring services, using telephone bank and using banking electronic services causes decreasing job stability and decreases job security. This study is one of the newest studies in e-banking; therefore, researchers are suggested to do some studies and aim to extend the result of this study in this context

\section{References}

[1] Adewoye, J. O. (2013). Impact of Mobile Banking on Service Delivery in the Nigerian Commercial Banks. International Review of Management and Business Research , 2 (2) 333-343 www.irmbrjournal.com (16-5-2014).

[2] Alabar, T. T. (2012). Electronic banking service and customer satisfaction in the Nigerian banking industry. International Journal of business and management tomorrow, 2(3), 1-8. available at www.ijbmt.com. (30-6-2014).

[3] Alsajjan, B., and C. Dennis. (2010). Internet banking acceptance model: Cross-market examination. Journal of Business Research 63 (9-10): 957-963.

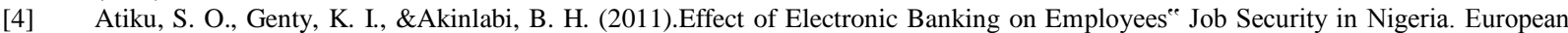
Journal of Humanities and Social Sciences 4(2) 68-84. (Special Issue), 2011. www.academia.edu/ (5-7-2014).

[5] Chi Shing.Y., B. K. Grantc, and D. Edgarc.(2007). Factors affecting the adoption of Internet banking in Hong Kong - implications for the banking sector. International Journal of Information Management 27 (5): 336-351.

[6] Dandapani, K. (2008). Internet banking services and credit union performance.Managerial Finance 34 (6):437-446.

[7] Hua, G. (2009). An Experimental Investigation of Online Banking Adoption in China. Journal of Internet Banking and Commerce, 14(1) 1-12. http://www.arraydev.com/commerce/jibc/ (5-6-2014).

[8] Jannatul, M. N. (2010). E-banking and customere satisfaction in Bangladesh: an analysis. International Review of Business Research Papers, 6(4) 145-156. www.bizresearchpapers.com/12.\%20Nupur.pdf (25-9-2014) 
[9] Olanipekun, W. D., Brimah, A. N., \&Ajagbe, S. T. (2013). Electronic Banking in Enhancing Human Resource Performance and Customer Satisfaction: Evidence from Guaranty Trust Bank PLC, Nigeria. International Journal of Business and Behavioral Sciences, 3 (4) 36-44. cprenet.com/uploads/archive/IJBBS_12-1227.pdf (20-9-2014).

[10] Saudi Arabia Monetory Agency (SAMA). (2010). "E-Banking Rules". Banking Technology Department, April 2010. 2-36.

[11] Shakerinia, Iraj. (1997). Security and job satisfaction and mental health.Tadbir Journal, No. 72, Khordad.

[12] Soltani, Iraj. (2009). The role of developing human resources in promoting organizations 'profitability.Governmental management journal (39) spring.

[13] Taghavifard, M., Zahedi, M., Torabi, M. (2010). Influential factors on using internet banking services by customers (case study of Melat bank). Iranian Research Institute for Information science and technology (27) 3.

[14] TeroPikkarainen, Kari Pikkarainen, HeikkiKarjaluoto, Seppo Pahnila (2004)«Consumer Acceptance Of Online Banking: An Extension Of The Technology Acceptance Model », InternetResearch, Vol. 14, No. 3, Pp. 224-235 . 